\title{
Areas of endemism of Cactaceae and the effectiveness of the protected area network in the Chihuahuan Desert
}

\author{
Héct or M. Hernán dez and CA RL os GómeZ-Hinostrosa
}

\begin{abstract}
We used distribution data of 121 cactus species endemic to the Chihuahuan Desert to test the effectiveness of the region's protected area network. The analysis of species distribution using a $30^{\prime}$ latitude $\times 30^{\prime}$ longitude grid facilitated the identification and categorization of areas of endemism. We found a low degree of coincidence between protected areas and the areas of cactus endemism, and only $63.6 \%$ of the 121 species occur in protected areas. A complementarity analysis showed that 10 of the protected areas contain the 77 species that occur in protected areas. The four top priority areas protect 65 (84.4\%) of these 77 species The 44 unprotected species are mainly micro-endemic and taxonomically distinctive taxa widely scattered in the region. The complementarity analysis applied to these species showed that all of them can be contained in a minimum of 24 grid squares, representing $32.9 \%$ of the total area occupied. Their strong spatial dispersion, along with their narrow endemism, is a major conservation challenge. We conclude that the current protected area network is insufficient to protect the rich assemblage of cacti endemic to the Chihuahuan Desert. Conservation efforts in this region should be enhanced by increasing the effectiveness of the already existing protected areas and by the creation of additional protected areas, specifically micro-reserves, to provide refuge for the unprotected species.
\end{abstract}

Keywords Biodiversity conservation, Cactaceae, complementarity, endemism, gap species, Mexico

This paper contains supplementary material that can be found online at http://journals.cambridge.org

\section{Introduction}

The environmental conditions of arid zones, especially 1 the low availability of water, have stimulated plant speciation and the evolution of unusual life forms, and a high proportion of the species of such areas are endemic, particularly in warm deserts (Cowling et al., 1999; Burke,

Héctor M. Hernández (Corresponding author) and Carlos GómezHinostrosa Departamento de Botánica, Instituto de Biología, Universidad Nacional Autónoma de México, Ciudad Universitaria, Deleg. Coyoacán, Apartado Postal 70-233, 04510 Mexico, D. F., Mexico. E-mail hmhm@ ibiologia.unam.mx

Received 19 January 2010. Revision requested 26 March 2010. Accepted 21 May 2010.
2004; Riemann \& Ezcurra, 2005). Endemic species have a high conservation priority because they are exclusive to a region and are often geographically restricted and ecologically infrequent. Plant communities in some desert areas are thus irreplaceable (Pressey, 1999).

An example of such an area is the Chihuahuan Desert. With an estimated 3,500 plant species (Henrickson \& Johnston, 2004) and a high degree of plant and animal endemism (Johnston, 1977; Minckley, 1977; Pinkava, 1984), the region is one of the most diverse deserts. The Cactaceae is the most emblematic plant group of this region (Hernández \& Gómez-Hinostrosa, 2005) and some areas within it have the highest number, globally, of cactus species per unit area (Hernández et al., 2001). The region has a total of 329 native cactus species in 39 genera, with 43 and $70 \%$ generic and species endemism, respectively (Hernández et al., 2004).

The Cactaceae is a highly threatened plant family and the IUCN Global Cactus Assessment (2010), currently in progress, is confirming that c. $33 \%$ of the species are threatened. The principal factor affecting the conservation status of Mexican cacti is habitat deterioration as the result of a diversity of factors, including agricultural development, goat husbandry, mining and road construction. However, the collection of individual plants for ornamentals, which affects the rarest and most threatened species, is also a major threat (Hernández \& Gómez-Hinostrosa, 2005). Although Mexican law prohibits collection of threatened species of flora and fauna, there is evidence that cactus plants and seeds are still being collected illegally (Robbins \& Bárcenas, 2003).

Protected areas are considered the most effective instrument for in situ biodiversity conservation, with $>100,000$ such areas worldwide covering $>12 \%$ of the Earth's land surface (Chape et al., 2008). However, protected areas do not always achieve their objective of protecting biodiversity. Many are not enforced and/or are not effectively managed, and are affected by poaching, habitat loss and fragmentation. Frequently they are inadequately designed and do not coincide with high priorities such as areas of high habitat diversity, species richness and/or endemism (Margules \& Pressey, 2000; Ervin, 2003; Rodrigues et al., 2004).

Here we use the endemic Cactaceae of the Chihuahuan Desert as biodiversity surrogates. We analysed the species' distributions to answer four questions regarding the effectiveness of the region's protected areas: (1) What is the degree of coincidence between the richest areas of endemism and 
protected areas? (2) What percentage of the species and their populations are in protected areas? (3) What is the relative importance of each of the protected areas for conserving these species? (4) Where are the major gaps in the conservation of these species?

\section{Study area}

The c. 533,600 km² (Hernández et al., 2010) Chihuahuan Desert is the largest area containing xeric ecosystems in North America. The region extends from the central
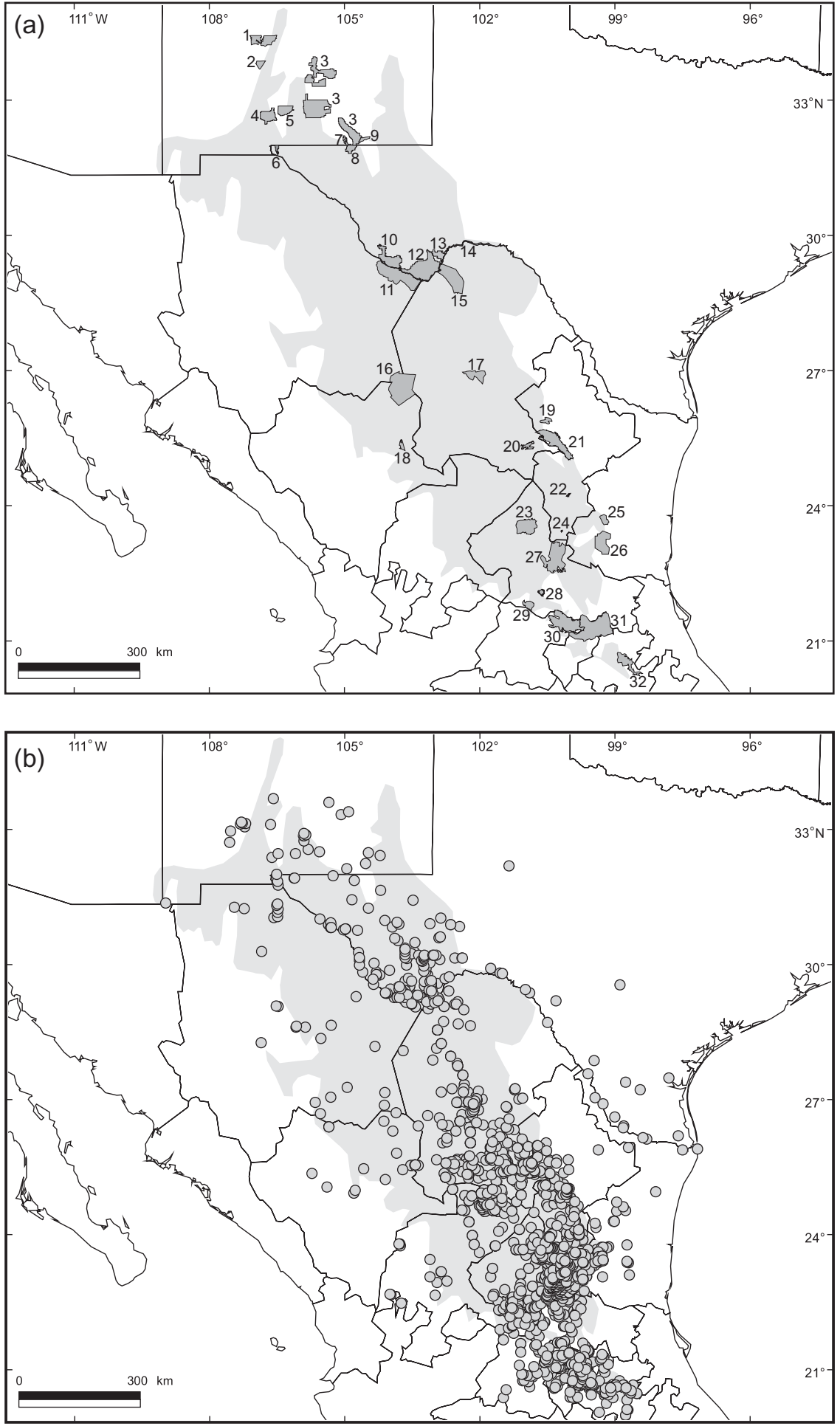

FIG. 1 (a) The 32 protected areas in the Chihuahuan Desert (area shaded light grey); the numbering is approximately north-south (see Table 1 for the names of the areas). (b) Distribution of endemic cactus species in the Chihuahuan Desert; each dot represents the locality of one to several species. 
Mexico states of Guanajuato, Querétaro and Hidalgo to southern Texas, New Mexico, and a small part of Arizona, and is bordered by the Sierra Madre Occidental and the Sierra Madre Oriental (Fig. 1a). The ecological and climatic characteristics of this region have been described elsewhere (Shreve, 1942; Johnston, 1977; Schmidt, 1979; Medellín-Leal, 1982; Henrickson \& Johnston, 1986; Hernández \& GómezHinostrosa, 2005; Hernández, 2006). Thirty-two protected areas cover c. $37,547 \mathrm{~km}^{2}$ of this desert ( $7 \%$ of the total area; Fig. 1a, Table 1).

\section{Methods}

We regarded as endemic those cactus species essentially restricted to the Chihuahuan Desert as delineated by Hernández \& Gómez-Hinostrosa (2005). A total of 229 cactus species endemic to this region have been recorded (Hernández et al., 2004). From these we selected a subset of
121 species (Appendix) that are well studied taxonomically and for which the geographical distributions are well documented. The ranges of most of these species are strictly restricted to the Chihuahuan Desert (Hernández \& Gómez-Hinostrosa, 2005). However, we also included a few species whose geographical range is centred in the region but that also have a small part $(\leq 5 \%)$ of their populations outside the region (Fig. 1b). We follow Hunt's (2006) taxonomic nomenclature.

We used 3,786 geo-referenced records from a database of cactus collections for North and Central America developed by $\mathrm{HMH}$ and collaborators. The database is a compilation of specimen data of Cactaceae from 35 herbaria in Mexico and several other countries. The number of specimen records per species is 1-219 (Appendix).

To identify areas of endemism we overlaid the records of the 121 species on a map with a $30^{\prime}$ latitude $\times 30^{\prime}$ longitude grid and ranked the grid squares according to

TABLE 1 The 32 protected areas in the Chihuahuan Desert (CONANP, 2008; WDPA, 2008; see numbered locations in Fig. 1a).

\begin{tabular}{|c|c|c|c|c|}
\hline Protected area & Category* & Location & Area $\left(\mathrm{km}^{2}\right)$ & No. of cactus species \\
\hline 1, Sevilleta & NWR & New Mexico & 929 & 0 \\
\hline 2, Bosque del Apache & NWR & New Mexico & 231 & 0 \\
\hline 3, Lincoln & NF & New Mexico & 4,466 & 1 \\
\hline 4, Jornada Experimental Range & $\mathrm{EC}$ & New Mexico & 784 & 0 \\
\hline 5, White Sands & NM & New Mexico & 578 & 0 \\
\hline 6, Franklin Mountains & SP & Texas & 97 & 1 \\
\hline 7, Brokeoff Mountains & WSA & New Mexico & 124 & 1 \\
\hline 8, Guadalupe Mountains & NP & Texas & 349 & 0 \\
\hline 9, Carlsbad Caverns & NP & New Mexico & 189 & 0 \\
\hline 10, Big Bend Ranch & SP & Texas & 1,134 & 6 \\
\hline 11, Cañón de Santa Elena & APFF & Chihuahua & 2,772 & 5 \\
\hline 12, Big Bend & NP & Texas & 2,865 & 8 \\
\hline 13, Black Gap & WMA & Texas & 404 & 1 \\
\hline 14, Rio Grande & NSR & Texas & 388 & 2 \\
\hline 15, Maderas del Carmen & APFF & Coahuila & 2,083 & 4 \\
\hline 16, Mapimí & $\mathrm{BR}$ & Durango, Chihuahua, Coahuila & 3,423 & 1 \\
\hline 17, Cuatro Ciénegas & APFF & Coahuila & 843 & 12 \\
\hline 18, Cañón de Fernández & SP & Durango & 170 & 1 \\
\hline 19, Sierra El Fraile y San Miguel & SZEC & Nuevo León & 235 & 1 \\
\hline 20, Serranía de Zapalinamé & SZEC & Coahuila & 257 & 5 \\
\hline 21, Cumbres de Monterrey & NP & Coahuila, Nuevo León & 1,773 & 6 \\
\hline 22, Sandía el Grande & SZEC & Nuevo León & 19 & 1 \\
\hline 23, Huiricuta & NSS & San Luis Potosí & 1,400 & 7 \\
\hline 24, San Elías & SZEC & Nuevo León & 6 & 2 \\
\hline 25, Altas Cumbres & SZEC & Tamaulipas & 312 & 3 \\
\hline 26, El Cielo & $\mathrm{BR}$ & Tamaulipas & 1,445 & 5 \\
\hline 27, Real de Guadalcázar & $\mathrm{SP}$ & San Luis Potosí & 2,570 & 37 \\
\hline 28, Sierra de Álvarez & $\mathrm{ZPF}$ & San Luis Potosí & 169 & 1 \\
\hline 29, Gogorrón & NP & San Luis Potosí & 369 & 1 \\
\hline 30, Sierra Gorda de Guanajuato & $\mathrm{BR}$ & Guanajuato & 2,368 & 17 \\
\hline 31, Sierra Gorda & $\mathrm{BR}$ & Querétaro & 3,835 & 16 \\
\hline 32, Barranca de Metztitlán & $\mathrm{BR}$ & Hidalgo & 960 & 11 \\
\hline Total & & & 37,547 & 77 \\
\hline
\end{tabular}

${ }^{*}$ APFF, Area of Protection of Flora and Fauna; BR, Biosphere Reserve; EC, Experimental Camp; NF, National Forest; NM, National Monument; NP, National Park; NWR, National Wildlife Refuge; NSS, Natural Sacred Site; NSR, Natural Scenic River; SP, State Park; SZEC, Special Zone under Ecological Conservation; WMA, Wildlife Management Area; WSA, Wildlife Study Area; ZPF, Zone of Forest Protection 

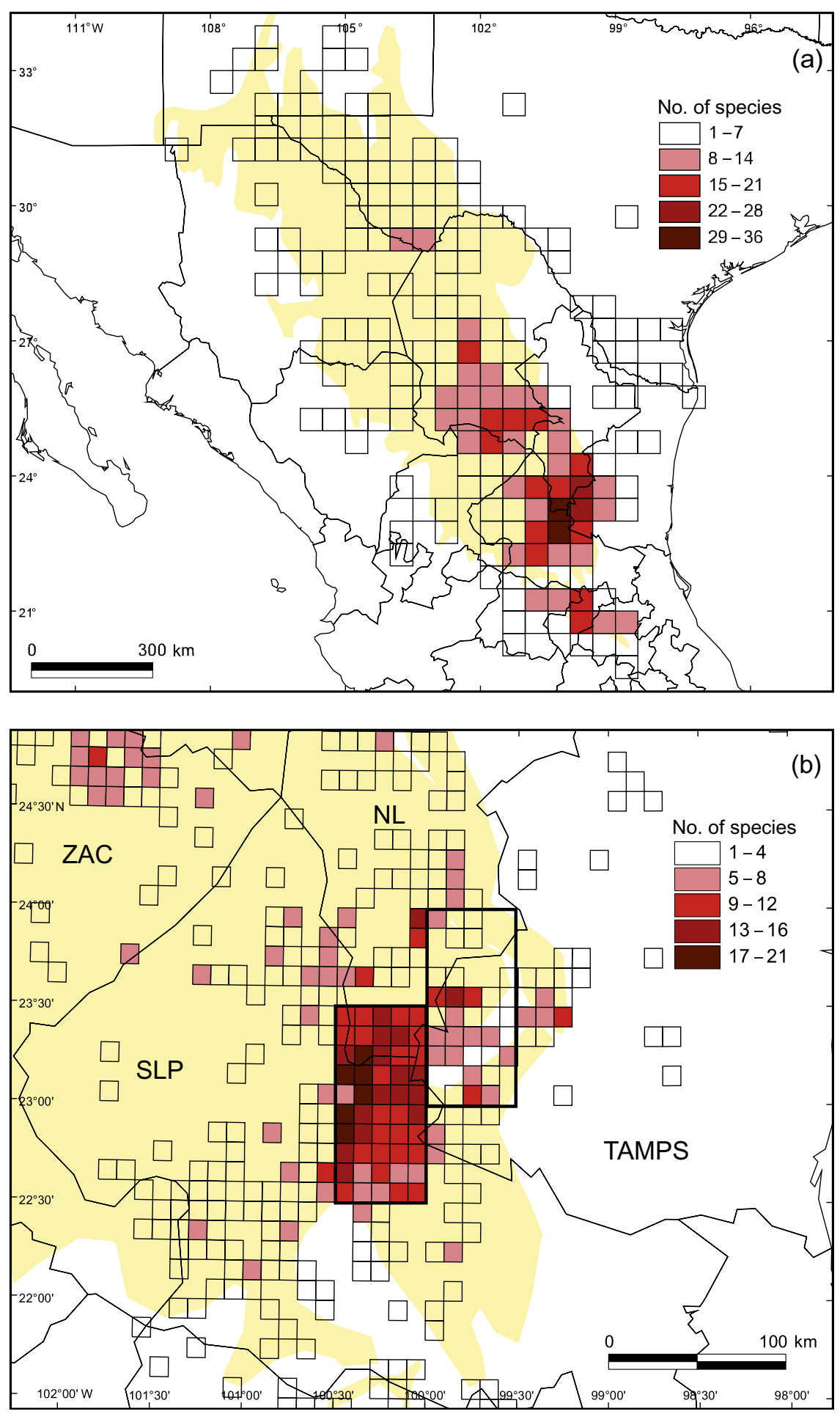

Fig. 2 (a) Pattern of species richness of endemic cacti in the Chihuahuan Desert at a scale of $30^{\prime}$ latitude $\times 30^{\prime}$ longitude. Grid squares are ranked according to their respective number of species: rank I $=29-36$ spp., rank II $=22-28$ spp., rank III $=15-21$ spp., rank IV $=$ 8-14 spp., rank V = 1-7 spp. (b) Detail of pattern of species richness in the rank I (left pair of $30^{\prime} \times 30^{\prime}$ grid squares) and rank II (right pair of $30^{\prime} \times 30^{\prime}$ grid squares) areas of endemism (delimited by thicker line) at a scale of $6^{\prime} \times 6^{\prime}$. State abbreviations: NL, Nuevo León; SLP, San Luis Potosí; TAMPS, Tamaulipas; ZAC, Zacatecas.

their respective number of species. Areas with $\geq 22$ species were further analysed at a scale of $6^{\prime} \times 6^{\prime}$. To compare the geographical configuration of the areas of endemism with that of the protected areas, the percentage of the areas of endemism overlapping with protected areas was calculated.

We assessed the efficacy of the protected areas in protecting individual cactus species by overlaying the geo-referenced 
records on the map of protected areas (Fig. 1). We estimated the degree of protection afforded individual species by calculating the percentage of known localities of each species situated within one or more protected areas. The number of known localities per species was taken from Hernández et al. (2010). Following Hernández et al. (2010) a locality is defined here as a point displayed on a map that is separated from its nearest neighbour by at least $797.9 \mathrm{~m}$, the radius of a $2-\mathrm{km}^{2}$ circle. Points located within this radius were considered part of the same locality.

Protected area shape files were obtained from CONANP (2008), Bezaury-Creel et al. (2007) and WDPA (2008). For spatial analyses we used ArcView v. 3.2 (ESRI, Redlands, USA).

The complementarity principle has been used to select minimal sets of areas that are complementary in terms of the features of a region, with the aim of maximizing the chances of achieving representative networks of reserves (Humphries et al., 1991; Vane-Wright et al., 1991). The first step is to select a priority choice, which corresponds to the area containing the highest number of species. From this, the remaining areas are ordered according to their contribution of additional species not found in the areas of higher priority. The Real de Guadalcázar State Park was the first priority, and the 31 other protected areas were prioritized according to their complementarity values. The complementarity value was calculated for each protected area as $(A S \times 100) / R C$, where $A S$ is number of unique, additional species not found in the first priority area or in higher priority areas, and $R C$ is the residual complement, calculated as the difference of the complement (the total number of species considered that occur in protected areas; $77 \mathrm{spp}$.) and the number of species in the first priority area (37 spp.). In addition to the complementarity analysis of the 77 species occurring within protected areas we determined the near minimum area set for the 44 species that occur outside the 32 protected areas using the $30^{\prime} \times 30^{\prime}$ grid squares as the units of analysis.

\section{Results}

Fig. 2a shows the pattern of species richness at a resolution of $30^{\prime} \times 30^{\prime}$. The number of endemic cactus species per grid square was $1-36$. We categorized the grid squares according to the number of endemic species present: rank I (29-36), rank II (22-28), rank III (15-21), rank IV (8-14), and rank V $(1-7)$. There are two general areas of endemism of ranks I and II in the south-east (Fig. 2a). There are two grid squares of rank I, the cactus flora of which was recently described (Hernández et al., 2001; Gómez-Hinostrosa \& Hernández, 2000): the Huizache and Mier y Noriega grid squares, with 36 and 32 species respectively. Fig. $2 \mathrm{~b}$ shows the spatial pattern of the rank I and II areas at a finer scale $\left(6^{\prime} \times 6^{\prime}\right)$. The richest areas lie mainly towards the west of the rank I area.

The two grid squares of rank II (Miquihuana and Tula with 27 and 22 species, respectively) lie to the north-east and east of the Mier y Noriega grid square (Fig. 2a). Around the rank I and II areas there is a group of rank III grid squares, some of which are contiguous with the rank I and II squares of endemism, although others are further away, in the Queretaroan arid zone, along the Sierra de Parras, in southern Coahuila and Cuatro Ciénegas.

The two rank I grid squares have a total surface area of $5,674 \mathrm{~km}^{2}, 41.1 \%\left(2,334 \mathrm{~km}^{2}\right)$ of which overlaps with the Real de Guadalcázar and San Elías protected areas (Table 2). The two rank II squares are totally unprotected. Table 2 summarizes the degree of protection of the different areas at a scale of $30^{\prime} \times 30^{\prime}$.

Fig. 3 shows the number of species in each of the numbered protected areas. Four areas (Real de Guadalcázar, 37 species; Sierra Gorda de Guanajuato, 17; Sierra Gorda, 16; Cuatro Ciénegas, 12) protect, at least in theory, 65 species; i.e. $84.4 \%$ of the species occurring in the protected areas and $53.7 \%$ of the species in our sample of 121 species. Sixteen of the areas protect $0-1$ species in our sample; these areas are mostly located in the north of the region (Figs 1a \& 3).

Overall 892 localities (24\% of the 3,786 geo-referenced localities) lie within protected areas. For each species the Appendix provides the percentage of localities occurring in protected areas of the total number of localities known (Hernández et al., 2010). Only nine species (7.4\%) are fully protected (i.e. $100 \%$ of localities in protected areas) and $50 \%$ or less of the number of localities of 59 species (48.8\%) are protected.

The complementarity analysis (Table 3 ) shows that 10 of the 32 reserves together shelter all 77 species, of our subset

TABLE 2 Degree of protection of different areas of cactus endemism at a scale of $30^{\prime}$ latitude $\times 30^{\prime}$ longitude. Ranks were defined according to the number of species found per grid square: rank I (29-36 spp.), rank II (22-28 spp.), rank III (15-21 spp.), rank IV (8-14 spp.) and rank V (1-7 spp.).

\begin{tabular}{lccc}
\hline Degree of endemism & No. of grid squares & Total area $\left(\mathrm{km}^{2}\right)$ & $\begin{array}{c}\text { Area protected, km } \\
(\% \text { of total) }\end{array}$ \\
\hline Rank I & 2 & 5,674 & $2,334(41.1)$ \\
Rank II & 2 & 5,652 & 0 \\
Rank III & 13 & 36,684 & $4,182(11.4)$ \\
Rank IV & 28 & 78,584 & $9,780(12.4)$ \\
Rank V & 92 & 250,969 & $16,424(6.5)$ \\
\hline
\end{tabular}




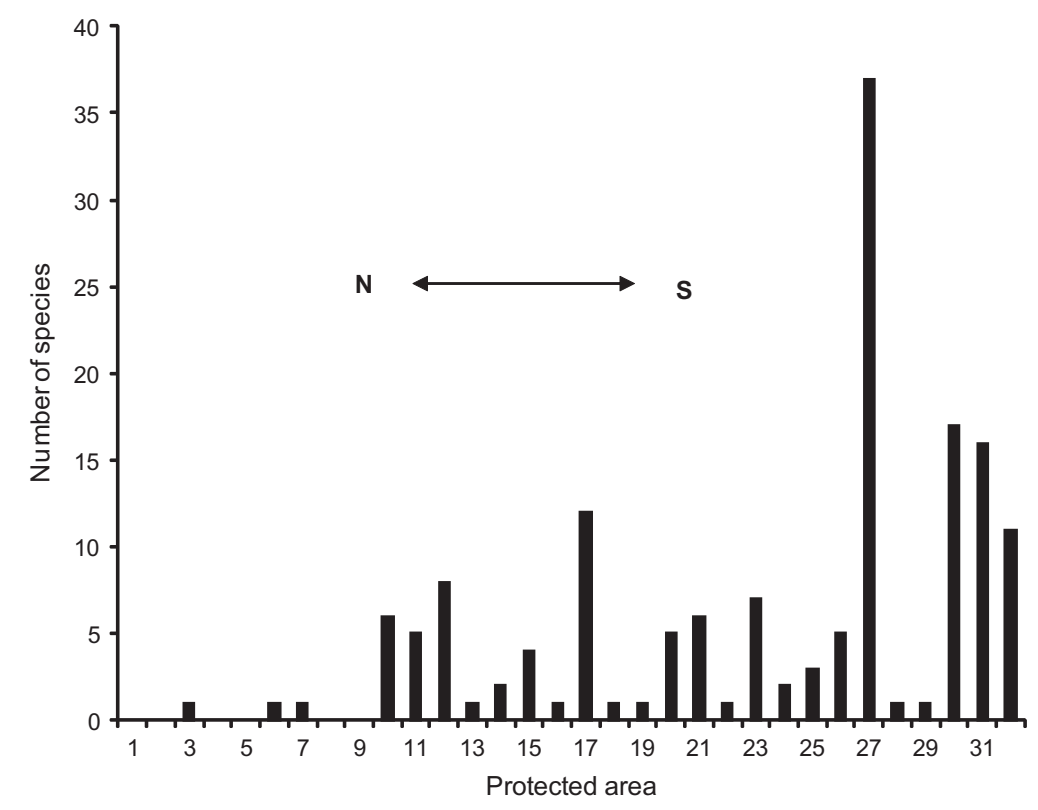

FIG. 3 Number of species of endemic cacti in each numbered protected area. The numbers in the $\mathrm{x}$-axis correspond to the numbered protected areas in Fig. 1a and Table 1.

of 121 species, that occur in protected areas; this is the optimal solution for the conservation of these species. The four top priority areas protect $65(84.4 \%)$ of the species. The complementarity analysis applied to the areas occupied by the 44 species occurring exclusively outside protected areas shows that of the 73 grid squares (a total area of $208,000 \mathrm{~km}^{2}$ ) in which these species occur, a minimum of 24 (32.9\% of the squares) are necessary to contain all of the species. None of the grid squares contain high numbers of these 44 species, and the difference in number of unique species between the first priority area ( 5 species) and fifth priority area (1) is small (Table 4, Fig. 4).

\section{Discussion}

Although the protected areas of the Chihuahuan Desert cover $7 \%$ of the region's area there is a low degree of coincidence with the richest areas of cactus endemism (Table 2). With the exception of the rank I areas of endemism, $41.1 \%$ of which are protected by the Real de Guadalcázar State Park and another, smaller protected area, the protection of areas of cactus endemism is low or non-existent. With respect to the protection of individual species, almost two thirds (77 species) are protected but 44 , including several of the rarest endemic species, are unprotected. It is not only species of cacti that are endemic to the Chihuahuan Desert. Approximately one-third of the region's plant species are endemic (Johnston, 1977) and there are also high levels of endemism amongst reptiles and freshwater fish (Miller, 1977; Minckley, 1977; Morafka, 1977).

The protected areas of Real de Guadalcázar, Sierra Gorda de Guanajuato, Cuatro Ciénegas and Sierra Gorda are particularly important because of the number of species they protect and for their high complementarity. The 2,570 $\mathrm{km}^{2}$ Real de Guadalcázar State Park was gazetted to protect the habitat of the 76 cactus species in the area. The Park is the richest centre of cactus diversity globally (Hernández et al., 2001), and has the richest number of threatened (Hernández \& Bárcenas, 1995) and endemic cactus species. However, although the Park was gazetted in 1997 several portions of the reserve are under severe pressure. In an assessment of the effectiveness of federal protected areas in Mexico Figueroa \& Sánchez-Cordero (2008) found that two protected areas important for the conservation of Chihuahuan Desert Cactaceae, Cuatro Ciénegas and Sierra Gorda, were 'weakly effective' and 'non-effective' respectively, because of high rates of land use and land cover change. The Real de Guadalcázar and Sierra Gorda de Guanajuato were not included in the study because the former is a state reserve under the jurisdiction of the government of San Luis Potosí and the latter was decreed only in 2008.

The 44 cactus species that do not lie within any protected area are some of the most taxonomically distinctive taxa of Mexican Cactaceae: the monotypic genus Geohintonia (G. mexicana), the two members each of the genera Aztekium (A. hintonii and A. ritteri) and Pelecyphora (P. aselliformis and $P$. strobiliformis), and one species of Acharagma (A. aguirreanum), all genera endemic to the Chihuahuan Desert. This group also includes several species belonging to other genera endemic to the Chihuahuan Desert (Ariocarpus, Thelocactus and Turbinicarpus).

The most critical of these species are the 20 that occur in only a single $30^{\prime} \times 30^{\prime}$ square (Table 4 ). Sixteen of the 24 grid squares prioritized by the complementarity analysis contain 1-2 of these narrow endemics. Narrow endemism is a prominent phenomenon amongst Mexican Cactaceae, and many of these microendemics have extremely small 
TABLE 3 Results of the complementarity analysis of the 32 protected areas of the Chihuahuan Desert, considering the 77 cactus species that occur in these protected areas (Fig. 1a).

\begin{tabular}{lccc}
\hline Protected area & Number of unique species & Complementarity value (\%) & Priority \\
\hline 27, Real de Guadalcázar & 37 & & 1 \\
30, Sierra Gorda de Guanajuato & 15 & 37.5 & 2 \\
17, Cuatro Ciénegas & 9 & 22.5 & 3 \\
31, Sierra Gorda & 4 & 10.0 & 4 \\
32, Barranca de Metztitlán & 3 & 7.5 & 5 \\
25, Altas Cumbres & 3 & 7.5 & 5 \\
15, Maderas del Carmen & 2 & 5.0 & 6 \\
21, Cumbres de Monterrey & 2 & 5.0 & 6 \\
26, El Cielo & 1 & 2.5 & 7 \\
28, Sierra de Álvarez & 1 & 2.5 & 7 \\
\hline
\end{tabular}

distribution ranges. For example, Mammillaria humboldtii, Mammillaria schwarzii, Opuntia chaffeyi, Thelocactus hastifer, Turbinicarpus ysabelae and Turbinicarpus zaragozae occur in areas of $<6 \mathrm{~km}^{2}$ (Hernández et al., 2010). The microendemic nature of these species, along with their high taxonomic distinctiveness, is a clear reflection of the high conservation value and high degree of irreplaceability of the areas inhabited by them (May, 1990; Vane-Wright et al., 1991; Pressey, 1999).

The simplest solution to protect the 44 unprotected species would be the creation of additional reserves. The optimal size for any such reserves is, however, difficult to resolve (Primack, 2006; Hunter \& Gibbs, 2007, and refer- ences therein). In practice, reserve size should be determined following a consideration of the complex combination of biological, political and economic factors that make every situation unique (Hunter \& Gibbs, 2007). A large number of reserves would be required to protect the 44 species and extremely small reserves may have several disadvantages: they may not be adequate to support long-term populations and ecosystem processes, they usually cover a narrower range of environmental conditions, and reserves of $<100$ ha may not be sufficiently large to encompass the diversity of a region, especially considering that parts of the Chihuahuan Desert have high beta diversity (Goettsch \& Hernández, 2006; Hernández et al., 2008).

TABLE 4 Results of the complementarity analysis of the $30^{\prime}$ latitude $\times 30^{\prime}$ longitude grid squares containing the 44 cactus species that do not occur in protected areas (Fig. 1a). Grid squares are named according to the largest city or town.

\begin{tabular}{|c|c|c|c|c|}
\hline Grid square name & Location & $\begin{array}{l}\text { No. of species (no. } \\
\text { in a single grid square) }\end{array}$ & $\begin{array}{l}\text { Complementarity } \\
\text { value }(\%)\end{array}$ & Priority \\
\hline San Luis Potosí & $22^{\circ} 00^{\prime}-22^{\circ} 30^{\prime} \mathrm{N}, 100^{\circ} 30^{\prime}-101^{\circ} 00^{\prime} \mathrm{W}$ & $5(2)$ & & 1 \\
\hline Miquihuana & $23^{\circ} 30^{\prime}-24^{\circ} 00^{\prime} \mathrm{N}, 99^{\circ} 30^{\prime}-100^{\circ} 00^{\prime} \mathrm{W}$ & 4 & 10.3 & 2 \\
\hline Mazapil & $24^{\circ} 30^{\prime}-25^{\circ} 00^{\prime} \mathrm{N}, 101^{\circ} 30^{\prime}-102^{\circ} 00^{\prime} \mathrm{W}$ & 3 & 7.7 & 3 \\
\hline Ramos Arizpe & $25^{\circ} 30^{\prime}-26^{\circ} 00^{\prime} \mathrm{N}, 100^{\circ} 30^{\prime}-101^{\circ} 00^{\prime} \mathrm{W}$ & $3(1)$ & 7.7 & 3 \\
\hline Galeana & $24^{\circ} 30^{\prime}-25^{\circ} 00^{\prime} \mathrm{N}, 100^{\circ} 00^{\prime}-100^{\circ} 30^{\prime} \mathrm{W}$ & $3(1)$ & 7.7 & 3 \\
\hline Tolimán & $20^{\circ} 30^{\prime}-21^{\circ} 00^{\prime} \mathrm{N}, 99^{\circ} 30^{\prime}-100^{\circ} 00^{\prime} \mathrm{W}$ & $3(2)$ & 7.7 & 3 \\
\hline Parras & $25^{\circ} 00^{\prime}-25^{\circ} 30^{\prime} \mathrm{N}, 102^{\circ} 00^{\prime}-102^{\circ} 30^{\prime} \mathrm{W}$ & $2(1)$ & 5.1 & 4 \\
\hline Guanajuato & $21^{\circ} 00^{\prime}-21^{\circ} 30^{\prime} \mathrm{N}, 101^{\circ} 00^{\prime}-101^{\circ} 30^{\prime} \mathrm{W}$ & $2(1)$ & 5.1 & 4 \\
\hline Querétaro & $20^{\circ} 30^{\prime}-21^{\circ} 00^{\prime} \mathrm{N}, 100^{\circ} 00^{\prime}-100^{\circ} 30^{\prime} \mathrm{W}$ & $2(2)$ & 5.1 & 4 \\
\hline Tula & $23^{\circ} 00^{\prime}-23^{\circ} 30^{\prime} \mathrm{N}, 99^{\circ} 30^{\prime}-100^{\circ} 00^{\prime} \mathrm{W}$ & 2 & 5.1 & 4 \\
\hline Linares & $24^{\circ} 30^{\prime}-25^{\circ} 00^{\prime} \mathrm{N}, 99^{\circ} 30^{\prime}-100^{\circ} 00^{\prime} \mathrm{W}$ & $2(2)$ & 5.1 & 4 \\
\hline Estación Mezquite & $31^{\circ} 00^{\prime}-31^{\circ} 30^{\prime} \mathrm{N}, 106^{\circ} 30^{\prime}-107^{\circ} 00^{\prime} \mathrm{W}$ & 1 & 2.6 & 5 \\
\hline Coneto de Comonfort & $24^{\circ} 30^{\prime}-25^{\circ} 00^{\prime} \mathrm{N}, 104^{\circ} 30^{\prime}-105^{\circ} 00^{\prime} \mathrm{W}$ & $1(1)$ & 2.6 & 5 \\
\hline East Mapimí & $26^{\circ} 30^{\prime}-27^{\circ} 00^{\prime} \mathrm{N}, 103^{\circ} 00^{\prime}-103^{\circ} 30^{\prime} \mathrm{W}$ & $1(1)$ & 2.6 & 5 \\
\hline Zacatecas & $22^{\circ} 30^{\prime}-23^{\circ} 00^{\prime} \mathrm{N}, 102^{\circ} 30^{\prime}-103^{\circ} 00^{\prime} \mathrm{W}$ & 1 & 2.6 & 5 \\
\hline Cuatro Ciénegas & $26^{\circ} 30^{\prime}-27^{\circ} 00^{\prime} \mathrm{N}, 102^{\circ} 00^{\prime}-102^{\circ} 30^{\prime} \mathrm{W}$ & 1 & 2.6 & 5 \\
\hline Cinco de Mayo & $25^{\circ} 00^{\prime}-25^{\circ} 30^{\prime} \mathrm{N}, 101^{\circ} 30^{\prime}-102^{\circ} 00^{\prime} \mathrm{W}$ & 1 & 2.6 & 5 \\
\hline San Luis de la Paz & $21^{\circ} 00^{\prime}-21^{\circ} 30^{\prime} \mathrm{N}, 100^{\circ} 30^{\prime}-101^{\circ} 00^{\prime} \mathrm{W}$ & $1(1)$ & 2.6 & 5 \\
\hline Matehuala & $23^{\circ} 30^{\prime}-24^{\circ} 00^{\prime} \mathrm{N}, 100^{\circ} 30^{\prime}-101^{\circ} 00^{\prime} \mathrm{W}$ & 1 & 2.6 & 5 \\
\hline Xichú & $21^{\circ} 00^{\prime}-21^{\circ} 30^{\prime} \mathrm{N}, 100^{\circ} 00^{\prime}-100^{\circ} 30^{\prime} \mathrm{W}$ & $1(1)$ & 2.6 & 5 \\
\hline Cerritos & $22^{\circ} 00^{\prime}-22^{\circ} 30^{\prime} \mathrm{N}, 100^{\circ} 00^{\prime}-100^{\circ} 30^{\prime} \mathrm{W}$ & $1(1)$ & 2.6 & 5 \\
\hline Ciudad del Maíz & $22^{\circ} 00^{\prime}-22^{\circ} 30^{\prime} \mathrm{N}, 99^{\circ} 30^{\prime}-100^{\circ} 00^{\prime} \mathrm{W}$ & $1(1)$ & 2.6 & 5 \\
\hline Metztitlán & $20^{\circ} 30^{\prime}-21^{\circ} 00^{\prime} \mathrm{N}, 98^{\circ} 30^{\prime}-99^{\circ} 00^{\prime} \mathrm{W}$ & $1(1)$ & 2.6 & 5 \\
\hline González & $25^{\circ} 30^{\prime}-26^{\circ} 00^{\prime} \mathrm{N}, 99^{\circ} 30^{\prime}-100^{\circ} 00^{\prime} \mathrm{W}$ & $1(1)$ & 2.6 & 5 \\
\hline
\end{tabular}




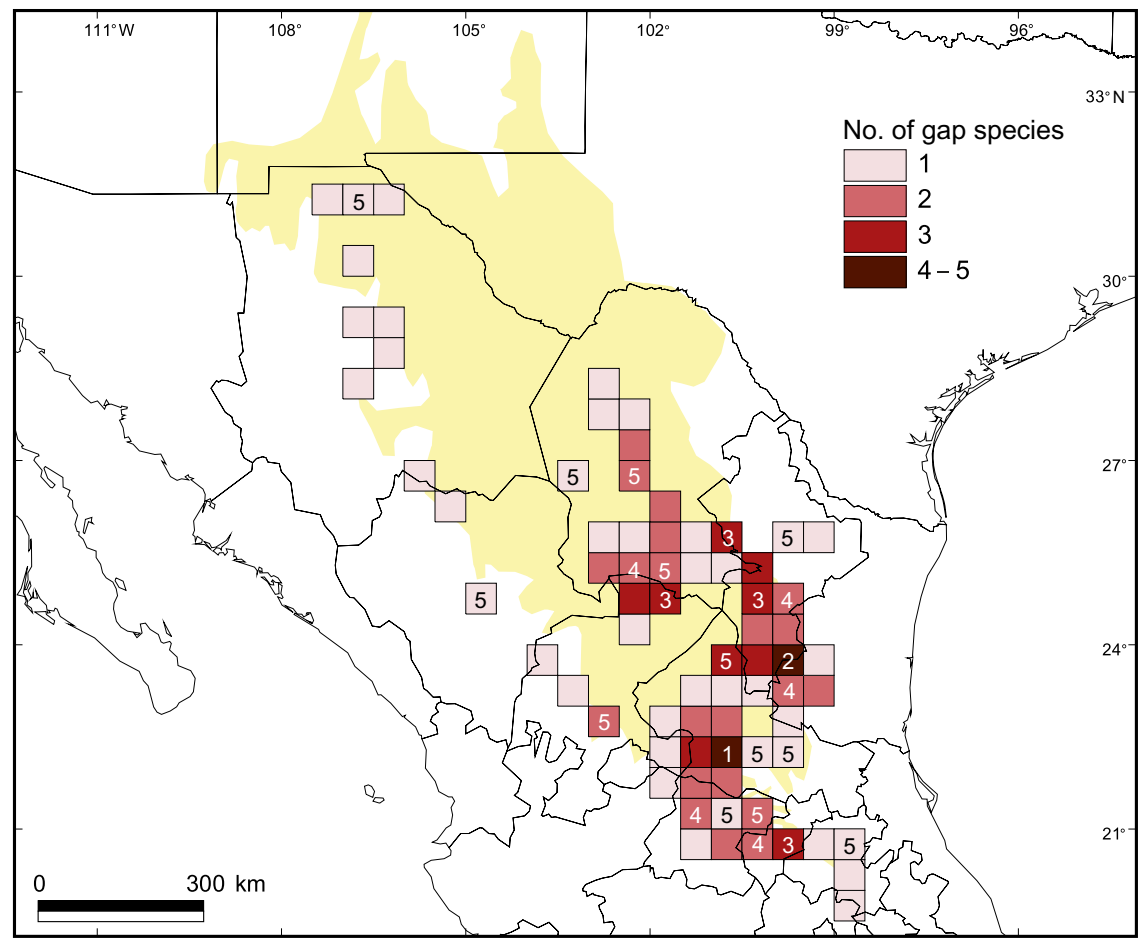

FIG. 4 Density map of unprotected species per half-degree cell. The numbers within some of the grid squares indicate the priority levels based on the results of the complementarity analysis (Table 4).

Nevertheless, despite these and other considerations, several examples demonstrate the practical value, as well as the ecological and genetic viability, of small protected areas for plants (Lesica \& Allendorf, 1992; Cowling et al., 2003). In the Valencian region of Spain a network of microreserves of 2-20 ha, established since 1994, has proved highly effective for protecting elements of the region's flora (Laguna et al., 2004; Laguna, 2008). The legal framework confers upon these micro-reserves 'permanent status and provides strong protection to plants and substrates while allowing traditional activities compatible with plant conservation' (Laguna et al., 2004). Similar networks have been successfully implemented in Eastern Europe and the Mediterranean region (Laguna et al., 2006; Laguna, 2008), and small-scale conservation approaches have also been used in the Cape Floristic Region of South Africa (Tansley, 1988; Cowling et al., 2003).

Another approach relevant in the context of microreserve networks is the Alliance for Zero Extinction (AZE). This joint initiative of 52 biodiversity conservation organizations, which is targeted at geographically restricted and highly threatened species, identifies and safeguards sites in most urgent need of conservation (Ricketts et al., 2005). We estimate that c. 40 cactus species endemic to the Chihuahuan Desert meet the criteria to be regarded as AZE species.

To protect the endemic flora of the Chihuahuan Desert we believe that a small-scale approach to in situ conserva- tion is necessary as a complement to the large, established protected areas. Such small reserves should not be conceived as an alternative to large protected areas but rather both should be perceived as complementary approaches to biodiversity conservation (Tansley, 1988; Cowling et al., 2003; Laguna et al., 2004).

The $7 \%$ of the Chihuahuan Desert under legal protection is less than the minimum $10 \%$ recommended by international organizations (SCBD, 2002, 2004) and less than the $12 \%$ of the warm desert areas protected globally (Chape et al., 2005). To improve the conservation of the Chihuahuan Desert Cactaceae several actions are required: increase the effectiveness of the protected areas, especially those with numerous, unique, taxonomically distinctive species, and create a network of micro-reserves to protect the habitat of the highest possible number of unprotected and threatened species.

\section{Acknowledgements}

We thank Fernando Chiang and two anonymous reviewers for constructive criticisms, Julio César Montero for technical advice in the preparation of the figures, Teresa Terrazas for providing locality data and María Eugenia Correa for GIS advice. Fieldwork was carried out under collecting permits FLOR-0004 and FLOR-0094, provided by Secretaría del Medio Ambiente y Recursos Naturales, Mexico. 


\section{References}

Bezaury-Creel, J.E., Ochoa, L.M. \& Torres, J.F. (2007) Áreas naturales protegidas estatales, del Distrito Federal y municipales de México. CD versión 1.o. CONABIO/CONANP/The Nature Conservancy/PRONATURA A.C., Mexico City, Mexico.

BURKE, A. (2004) A preliminary account of patterns of endemism in Namibia's Sperrgebiet-the succulent karoo. Journal of Biogeography, 31, 1613-1622.

Chape, S., Harrison, J., Spalding, M. \& Lysenko, I. (2005) Measuring the extent and effectiveness of protected areas as an indicator for meeting global biodiversity targets. Philosophical Transactions of the Royal Society, Series B, Biological Sciences, 360, 443-455.

Chape, S., Spalding, M. \& Jenkins, M. (eds) (2008) The World's Protected Areas. Status, Values and Prospects in the 21st Century. University of California Press, Berkeley, USA.

CONANP (Comisión Nacional de Áreas Naturales Protegidas) (2008) Http://www.conanp.gob.mx [accessed 15 January 2011].

Cowling, R.M., Esler, K.J. \& Rundel, P.W. (1999) Namaqualand, South Africa-an overview of a unique winter-rainfall desert ecosystem. Plant Ecology, 142, 3-21.

Cowling, R.M., Pressey, R.L., Rouget, M. \& Lombard, A.T. (2003) A conservation plan for a global biodiversity hotspot-the Cape Floristic Region, South Africa. Biological Conservation, 112, 191-216.

ERvin, J. (2003) Protected area assessments in perspective. BioScience, 53, 819-822.

Figueroa, F. \& Sánchez-Cordero, V. (2008) Effectiveness of natural protected areas to prevent land use and land cover change in Mexico. Biodiversity and Conservation, 17, 3223-3240.

Global Cactus Assessment (2010) Http://gca.group.shef.ac.uk/ [accessed 17 January 2011].

Goettsch, B. \& Hernández, H.M. (2006) Beta diversity and similarity among cactus assemblages in the Chihuahuan Desert. Journal of Arid Environments, 65, 513-528.

Gómez-Hinostrosa, C. \& Hernández, H.M. (2000) Diversity, geographical distribution, and conservation of Cactaceae in the Mier y Noriega region, Mexico. Biodiversity and Conservation, 9, 403-418.

Henrickson, J. \& Johnston, M.C. (1986) Vegetation and community types of the Chihuahuan Desert. In Second Symposium on the Resources of the Chihuahuan Desert Region, United States and Mexico (eds J.C. Barlow, A.M. Powell \& B. Timmermann), pp. 2039. Chihuahuan Desert Research Institute/Sul Ross State University, Alpine, USA.

Henrickson, J. \& Johnston, M.C. (2004) A Flora of the Chihuahuan Desert Region. Unpublished manuscript.

Hernández, H.M. (2006) La vida en los desiertos mexicanos. Fondo de Cultura Económica, Mexico City, Mexico.

Hernández, H.M. \& BárCenas, R.T. (1995) Endangered cacti in the Chihuahuan Desert. I. Distribution patterns. Conservation Biology, 9, 1176-1190.

Hernández, H.M., Goettsch, B., Gómez-Hinostrosa, C. \& Arita, H. (2008) Cactus species turnover and diversity along a latitudinal transect on the Chihuahuan Desert Region. Biodiversity and Conservation, 17, 703-720.

Hernández, H.M. \& Gómez-Hinostrosa, C. (2005) Cactus diversity and endemism in the Chihuahuan Desert region. In Biodiversity, Ecosystems and Conservation in Northern Mexico (eds J.-L. Cartron, G. Ceballos \& R.S. Felger), pp. 264-275. Oxford University Press, New York, USA.

Hernández, H.M., Gómez-Hinostrosa, C. \& Bárcenas, R.T. (2001) Diversity, spatial arrangement, and endemism of Cactaceae in the Huizache area, a hotspot in the Chihuahuan Desert. Biodiversity and Conservation, 10, 1097-1112.

Hernández, H.M., Gómez-Hinostrosa, C. \& Goettsch, B. (2004) Checklist of Chihuahuan Desert Cactaceae. Harvard Papers in Botany, 9, 51-68.

Hernández, H.M., Gómez-Hinostrosa, C. \& Hoffmann, G. (2010) Is geographical rarity frequent among the cacti of the Chihuahuan Desert? Revista Mexicana de Biodiversidad, 81, 163-175.

Humphries, C., Vane-Wright, D. \& Williams, P. (1991) Biodiversity reserves: setting new priorities for the conservation of wildlife. Parks, 2, 34-38.

Hunt, D. (comp.) (2006) The New Cactus Lexicon. DH Books, Milborne Port, England.

Hunter, Jr, M. \& Gibis, J. (2007) Fundamentals of Conservation Biology, 3rd edition. Blackwell Publishing, Malden, USA.

Johnston, M.C. (1977) Brief resume of botanical, including vegetational, features of the Chihuahuan Desert Region with special emphasis on their uniqueness. In Transactions of the Symposium on the Biological Resources of the Chihuahuan Desert Region, United States and Mexico (eds R.H. Wauer \& D.H. Riskind), pp. 335-359. National Park Service, Washington, DC, USA.

LAGUNA, E. (2008) La conservación de la biodiversidad aplicada a pequeña escala: la red valenciana de microrreservas de flora. In Biodiversidad (ed. S. Grisolía), pp. 249-263. Presidencia de la Generalitat Valenciana-Fundación Premios Jaime I, Valencia, España.

Laguna, E., Deltoro, V.I., Pèrez-Botella, J., Pèrez-Rovira, P., Serra, Ll., Olivares, A. \& Fabregat, C. (2004) The role of small reserves in plant conservation in a region of high diversity in eastern Spain. Biological Conservation, 119, 421-426.

Laguna, E., Deltoro, V.I., Serra, Ll. \& Pérez-Rovira, P. (2006) Taking microreserves from Spain to Slovenia. Plant Talk, 43, 18-22.

Lesica, P. \& Allendorf, F.W. (1992) Are small populations of plants worth preserving? Conservation Biology, 6, 135-139.

Margules, C.R. \& Pressey, R.L. (2000) Systematic conservation planning. Nature, 405, 243-253.

MAY, R.M. (1990) Taxonomy as destiny. Nature, 347, 129-130.

Medellín-Leal, F. (1982) The Chihuahuan Desert. In Reference Handbook on the Deserts of North America (ed. G.L. Bender), pp. 321-372. Greenwood Press, Westport, USA.

Mille R, R. (1977) Composition and derivation of the native fish fauna of the Chihuahuan Desert region. In Transactions of the Symposium on the Biological Resources of the Chihuahuan Desert Region, United States and Mexico (eds R.H. Wauer \& D.H. Riskind), pp. 365-381. National Park Service, Washington, DC, USA.

Minckley, W. (1977) Endemic fishes of the Cuatro Ciénegas basin, northern Coahuila, Mexico. In Transactions of the Symposium on the Biological Resources of the Chihuahuan Desert Region, United States and Mexico (eds R.H. Wauer \& D.H. Riskind), pp. 383-404. National Park Service, Washington, DC, USA.

Morafka, D. (1977) A biogeographical analysis of the Chihuahuan Desert through its herpetofauna. Biogeographica, 9, 1-313.

PinkaVA, D. (1984) Vegetation and flora of the Bolsón of Cuatro Ciénegas region, Coahuila, Mexico: summary, endemism and corrected catalogue. Journal of the Arizona-Nevada Academy of Science, 19, 23-47.

Pressey, R.L. (1999) Applications of irreplaceability analysis to planning and management problems. Parks, 9, 42-51.

PrimACK, R.B. (2006) Essentials of Conservation Biology, 4th edition. Sinauer Associates, Sunderland, USA.

Ricketts, T.H., Dinerstein, E., Boucher, T., Brooks, T.M., Butchart, S.H.M., Hoffmann, M. et al. (2005) Pinpointing and preventing imminent extinctions. Proceedings of the National Academy of Sciences, 102, 18497-18501. 
Riemann, H. \& Ezcurra, E. (2005) Plant endemism and natural protected areas in the peninsula of Baja California, Mexico. Biological Conservation, 122, 141-150.

Robiins, C. \& Bárcenas, R. (2003) Prickly Trade: Trade and Conservation of Chihuahuan Desert Cacti. TRAFFIC North America/WWF, Washington, DC, USA.

Rodrigues, A.S.L., Andelman, S.J., Bakarr, M.I., Boitani, L., Brooks, T.M., Cowling, R.M. et al. (2004) Effectiveness of the global protected area network in representing species diversity. Nature, 428, 640-643.

Schmidt, JR, R.H. (1979) A climatic delineation of the 'real' Chihuahuan Desert. Journal of Arid Environments, 2, 243-250.

Secretariat of the Convention on Biological Diversity (SCBD) (2002) Global Strategy for Plant Conservation. UNEP/CBD/BGCI, Montreal, Canada.

Secretariat of the Convention on Biological Diversity (SCBD) (2004) Decisions Adopted by the Conference of the Parties to the Convention on Biological Diversity at its Seventh Meeting. UNEP/ $\mathrm{CBD} / \mathrm{COP} / 7 / 21$, Montreal, Canada.

Shreve, F. (1942) The desert vegetation of North America. Botanical Review, 8, 195-246.

TAnsley, S.A. (1988) The status of threatened Proteaceae in the Cape flora, South Africa, and the implications for their conservation. Biological Conservation, 43, 227-239.
Vane-Wright, R.I., Humphries, C.J. \& Williams, P.H. (1991) What to protect?-systematics and the agony of choice. Biological Conservation, 55, 235-254.

WDPA (World Database on Protected Areas) (2008) Http:// www.wdpa.org [accessed 15 January 2011].

\section{Appendix}

The appendix for this article is available online at http:// journals.cambridge.org

\section{Biographical sketches}

Héctor M. Hernández studies the systematics and biogeography of Mexican Cactaceae, primarily in the Chihuahuan Desert, with the aim of developing tools for their conservation. He is also chairman of the IUCN Cactus and Succulent Plant Specialist Group. Carlos Gómez-Hinostrosa has extensive experience of the taxonomy of the Mexican Cactaceae and is a member of the IUCN Cactus and Succulent Plant Specialist Group. 